\title{
IMPLEMENTATION OF DISPUTE SETTLEMENT OUTSIDE THE COURT THROUGH THE INDONESIAN NATIONAL ARBITRATION AGENCY (BANI) BASED ON ISLAMIC JUSTICE
}

\author{
${ }^{1}$ Anis Mashdurohatun, Syaiful Khoiri Harahap, Gunarto \\ ${ }^{1}$ Faculty of Law, Sultan Agung Islamic University. Email: anism@unissula.ac.id
}

\begin{abstract}
In the current era of globalization, the economy's most prominent characteristic is the fast-paced nature that drives people to enter the free market and free competition. Proper implementation of what was agreed upon together is the hope of all parties bound in the agreement. Dispute resolution that arises in the implementation of an agreement can be settled through arbitration. The purpose of this study is to examine and analyze the truth about the implementation of dispute resolution outside the court through the Indonesian National Arbitration Board. It has been effective in providing legal certainty and justice. This study uses a sociolegal research approach (sociolegal research approach). The data used are primary and secondary data. In this analysis technique, the steps taken are collecting legal materials, both primary legal materials and secondary legal materials relating to the rule of law related to alternative dispute resolution, which is analyzed descriptively analytically. Research Findings found that the implementation of dispute resolution outside the court has not been effective because it has not provided legal certainty and justice. Weaknesses in the arrangement of third parties outside the arbitration agreement can participate in the dispute resolution process through arbitration, the settlement system, and the cancellation system of arbitration awarding outside the court through the Indonesian National Arbitration Board (BANI). The need for reconstruction of the provisions in Article 36, Article 46, and Article 70 of Law No. 30 of 1999 concerning Arbitration and Alternative Dispute Resolution.
\end{abstract}

Keywords: Dispute Settlement;BANI;Islamic Justice

Article Received: 18 October 2020, Revised: 3 November 2020, Accepted: 24 December 2020

\section{Introduction}

The world that is inhabited by humans has turned into a global village with a single economy system.

" The World is moving from trade countries to a single economy in one economy. One market place. $" 1$

In the current era of globalization, the economy's most prominent characteristic is the fast-paced nature that drives people to enter the free market and free competition. ${ }^{2}$ Proper implementation of what was agreed upon together is the hope of all parties bound in the agreement. ${ }^{3}$ This implies that the trade agreements that have been agreed upon are given legal certainty towards all rights and obligations arising from the trade agreement. Fulfillment of rights and obligations as agreed upon

${ }^{1}$ Suyud Margono, ADR (Alternative Dispute Resolutian) dan Arbitrase Proses Pelembagaan dan Aspek Hukum. Jakarta : Ghalia Indonesia, 2004. pp. 11.

2 Zaeni Asyhadie, Hukum Bisnis Prinsip dan Pelaksanaannya di Indonesia, 5th edition, Jakarta: Rajawali Pers, 2011, pp.231 will lead to a process of reciprocity between the parties, with the intention that the parties who have reached an agreement to enter into a trade agreement establish a lasting relationship, so that it can take place for the long term, and prevent the possibility of disputes.

But in reality, it is not uncommon that in the implementation of the agreement, there are disputes both originating from different perceptions/interpretations of the terms in the agreement as well as those originating from actions that can be categorized as defaults and acts against the law (onrechtmatigedaad). ${ }^{4}$ The existence of this dispute can impact on inefficient economic development, decreased productivity, infertility in the business world, and increased production costs.

${ }^{3}$ Djoko Imbawani Atmadjaja, Hukum Dagang Indonesia Sejarah, Pengertian dan Prinsip -prinsip Hukum Dagang, Cetakan ke-2, Malang: Setara Press, 2012, p.123

${ }^{4}$ Frans Hendra Winarta, Hukum Penyelesaian Sengketa Arbitrase Nasional Indonesia dan Internasional, Cetakan ke-2, Jakarta: Sinar Grafika, 2013, p.1 
In such circumstances, out of hundreds of business transactions that occur, it is impossible to avoid disputes/conflicts that require immediate resolution. ${ }^{5}$

Every community has various ways to obtain an agreement in the case process or to resolve disputes and conflicts. The method used in a particular dispute has consequences, both for the parties to the dispute and the community in the broadest sense. Because of these consequences, it is very necessary to channel certain disputes to a dispute resolution mechanism that is most appropriate for them. Several things need to be considered to choose the most appropriate mechanism, namely how the forms of the problems of the parties; what is expected by the parties to be achieved, both in the resolution of certain disputes or disputes that are more general in nature; and costs that can or are available to be borne by the parties. ${ }^{6}$

The settlement of disputes that arise in the implementation of an agreement basically can be resolved with a variety of options, like through the process of lawsuits in general justice and refinement judicial settlements. This choice is very dependent on the willingness of both parties agreed before the implementation of the agreement and the agreement after the dispute. ${ }^{7}$ The dispute resolution process that has been known for a long time is through litigation in court. Litigation processes tend to produce new problems because of their win-lose nature, unresponsiveness, timeconsuming litigation, and open to the public. ${ }^{8}$

Technically, the function of the court or the task of adjudicating is formulated as "examining and deciding cases." Deciding on a case or dispute is not always the same as "resolving" or "solution" or "solving" the case or dispute. Because sometimes, the judge's decision is likely to deepen the wounds or sharpen the dispute (essentially, the dispute was never resolved) even with the judge's decision

${ }^{5}$ Zaeni Asyhadie, Op. Cit, p. 231

${ }^{6}$ Gunawan Widjaja dan Ahmad Yani. Seri Hukum Bisnis : Hukum Arbitrase.Jakarta : PT Raja Grafindo Persada 2000, p. 3.

${ }^{7}$ Djoko Imbawani Atmadjaja. Op. C it, p. 124 containing potential or new dispute disputes. Based on the above, it is necessary to change the orientation from "deciding a case" to "completing a case." 9

The court, as one of the best-known ways of resolving disputes, will almost always try to be avoided by many parties. This is because the process and the time period is relatively long and protracted. After all, there are several levels in the court hierarchy that must be passed. Besides, also because the identity of the parties to the dispute will be known by the public, because the principle of the hearing conducted by the judiciary is basically open to the public. Certainly, for those who already have names in the business world, they don't like their identity being publicized through court cases, because they are worried that their guaranteed reliability will fade, especially among business partners, Delay in the resolution of trade disputes will result in the development of inefficient economic development, productivity decreases, and conversely production costs increase. This not only impedes the improvement in the welfare and progress of workers, but also harms consumers. Whereas dispute resolution outside the court is closed to the public (close door session) so that the confidentiality of the parties is guaranteed, the proceedings are faster and more efficient as well as a win-win solution. The process of resolving disputes outside the court avoids delays caused by administrative procedures as proceeded in a general court. ${ }^{10}$ The settlement of disputes outside the court is called Alternative Dispute Resolution.

One of the most popular and popular now is the way to resolve disputes through arbitration. Even now, the developed world is reluctant to enter into business relations without being associated with an arbitration agreement. Indeed, commercial arbitration has been regarded as business excellence for the developed world as an

${ }^{8}$ Frans Hendra Winarta, Op.Cit, p. 9

9 Joejoen Tjahjani. Peran Pengadilan dalam pelaksaan putusan arbitrase. Jurnal Independent Vol. 2 No. 1, p. 27

${ }^{10}$ Frans Hendra Winarta. Loc.Cit p. 9 
alternative to resolving business disputes through official justice, which generally takes a long time. 11

The business dispute resolution process pursued by the parties through an arbitration forum is a reality of changing human tendencies in society that must be accepted. If all this time the dispute resolution mechanism follows a structured pattern through the district court, the choice of the arbitration forum will prioritize the freedom of the parties in determining other forms of similar processes, but through a simpler mechanism and it is hoped that there will be no distortion in the mechanism of law enforcement. So the results can fulfill the sense of justice of the community.

Arbitration has become one of the models for resolving disputes outside the court, which is quite attractive, especially by business actors in resolving disputes in the trade that occurs between them. Business actors seek arbitration because arbitration offers several advantages over litigation dispute resolution through courts. Benefits offered by arbitration include: ${ }^{12}$

1) the examination process is relatively fast because the direct arbitration award is final, binding, and the examination of the case is limited in time;

2) the examination is carried out by the arbiter who is an expert in the subject matter of the relevant dispute;

3) the examination of cases confidentially takes place to guarantee the credibility of the business actors in dispute; and

11 Hayadi, M. Penyelesaian Bisnis Internasional melalui Arbitrase. Jurnal ilmu hukum, 2009. P. 7, see also Nugroho, J. Kajian Kritis Terhadap UU No 3 Tahun 1999 tentang Arbitrase dan Alternatif Penyelesain Sengketa Dalam Kaitannya Dengan Prinsip Kebebasan Berkontrak di Indonesia. Jurnal Hukum Argumentum, 2005, p. 1

12 Gatot Soemartono, Arbitrase dan Mediasi di Indonesia, Jakarta, Gramedia Pustaka Utama, 2006, pp. 1013

${ }^{13}$ The relative arbitration award can be implemented across national borders because the 1958 New York Convention on the Recognition and Implementation of the Foreign Arbitration Award (the New York Convention 1958 on Recognition and Enforcement of Foreign Arbitral Awards) which has been ratified by 150 countries, see: http: // www .uncitral.org / uncitral / en / uncitral_texts / arbitration /
4) decisions that can be carried out across national borders. ${ }^{13}$

Nevertheless, there are also weaknesses of arbitration that need to be examined, namely: ${ }^{14}$

1) there is potential to impede the arbitration process or the implementation of the arbitration award by parties who have bad intention through the process in court;

2) limited arbitrator authority;

3) decisions that require an executive order to be executed; ${ }^{15}$ and

4) the costs of litigation in arbitration are more expensive than in court because the parties bear the arbitrator's fees and the costs of conducting arbitration to the litigation.

The popularity of arbitration as a mechanism for resolving trade disputes is also supported through continuous efforts made by various parties driven by the United Nations Commission on International Trade Law (UNCITRAL) to develop and promote arbitration through efforts to harmonize arbitration law between countries, ${ }^{16}$ through the UNCITRAL Model Law on The International Commercial Arbitration (UNCITRAL Model Law) ${ }^{17}$ was adopted by UNCITRAL on June 21, 1985. The UNCITRAL Model Law was then amended on July 7, 2006. ${ }^{18}$ The UNCITRAL Model Law has been adopted as a national arbitration law by 99 countries and

NYConvention_status.html, accessed on 6 September 2014. The Republic of Indonesia has become an accessing country through Presidential Decree No. 34/1981 concerning Ratification of the Convention on the Recognition and Enforcement of Foreign Arbitral Awards

14 See: Enid E. Marshall, Gill: the Law of Arbitration,Sweet\& Maxwell, London, 2001, p. 3

${ }^{15}$ Compare: Gatot Soemartono, Op.cit.,pp. 14-15

${ }^{16}$ UNCITRAL, Digest of Case Law on the Model Law on International Commercial Arbitration, United Nations publication, Sales No. E.12.V.9, New York, Tahun 2012 , p. 1

${ }^{17}$ Official Records of the General Assembly, 40th Session, Supplement No. 17 (A/40/17), Annex I; United Nations publication, Sales No. E.95.V.18

${ }^{18}$ Ibid, . 
states. ${ }^{19}$ Through the UNCITRAL Model Law, differences in legal systems - common law systems and civil law systems - that apply in various countries are expected to be minimized in relation to arbitration law.

Indonesia reformed national arbitration law when the monetary crisis hit Indonesia in 1999, along with efforts to reform national economic law. Many have speculated that the renewal of Indonesia's arbitration law in 1999 was part of a policy package requested by the International Monetary Fund (IMF) in an effort to restore the confidence of foreign investors in the Indonesian legal system. ${ }^{20}$

Renewal of Indonesian arbitration law is carried out by promulgating Law No. 30/1999 concerning Arbitration and Alternative Dispute Resolution. Law No. 30/1999 replaces the old Indonesian arbitration law as regulated in Articles 615 through Article 651 of the Reglement op de Burgerlijk Rechtsvordering (S. 1847: 52 jo. S. 1849: 63) as a legacy from the Dutch East Indies Government. Law No. 30/1999 did not adopt the UNCITRAL Model Law, although some provisions have regulations that are identical to the provisions in the UNCITRAL Model Law.

Thus it is interesting to conduct an in-depth study of whether the implementation of dispute resolution outside the court through the Indonesian National Arbitration Board has been effective in providing legal certainty and justice.

\section{Research Methods}

This research is non-doctrinal legal research ${ }^{21}$ with a socio-legal research approach. The object under study is the law conceptualized as a meaningful symbol as a result of construction manifested in the

${ }^{19}$ UNCITRAL. Op.Cit

20 See: "Memorandum of Economic and Financial Policies" in The Jakarta Post, 15 May 1999, p. 5. In a document entitled "Supplementary Memorandum of Economic and Financial Policies - the Fifth Review under the Extended Agreement" attached to the letter of the Coordinating Minister for Economy, Finance and Industry to the IMF dated May 14, 1999 stating, among others, that the draft arbitration law has been submitted to the Parliament. form of articles in legislation. It is to uncover the reality of the object used hermeneutical theory ${ }^{22}$. The method of thinking used is the method of deductive thinking from this generalization then observed or studied specific things to be able to formulate hypotheses as a temporary answer or conclusion, then just do research inductively by studying the facts that exist specifically or individually, which then analyzed and the results will find a general conclusion/generalization. ${ }^{23}$

This research relies on the problem of the decision of the Indonesian National Arbitration Body (BANI). The initial step taken is to collect legal materials, both primary and secondary, with the subject. Secondary legal materials are legal materials that support primary legal materials, such as law books, journals, research results in the field of law, seminar results, and others. The legal materials will be traced through a literature study, reviewed and analyzed, then taken the essence of legal concepts, principles, or principles that are considered relevant to finding answers in accordance with the subject.

The data analysis technique is the process of categorizing data sequences, organizing them into patterns, categories, and basic units of description, distinguishing them from interpretation by giving significant meaning to the analysis, explaining the description patterns, and looking for relationships between the dimensions of the description. ${ }^{24}$ In compiling the conceptual framework, the formulations contained in the statutory regulations can be used as the basis of research, or to be examined. ${ }^{25}$

In this analysis technique, the steps taken are collecting legal materials, both primary legal materials and secondary legal materials relating to

\footnotetext{
${ }^{21}$ Soetandyo Wignjosoebroto, Hukum Paradigma, Metode dan Dinamika Masalahnya, Huma, Jakarta, 2002, p. 148

${ }^{22}$ Jazim Hamidi, Hermenetika Hukum, Yogyakarta, UII Press, 2005, p. 29

23 Mardalis, Metode Penelitian Suatu Pendekatan Proposal, Bumi Aksara, 1989, p. 22

${ }^{24}$ Iskandar, Metode Penelitian Kualitatif, Jakarta. Gaung Persada, 2009, p. 136.

${ }^{25}$ Soerjono Soekanto, Pengantar Penelitian Hukum, UI-PRESS, 2008, p.53
} 
the rule of law related to alternative dispute resolution, which is analyzed descriptively analytically.

\section{Research Results and Discussion}

The data analysis technique is the process of categorizing data sequences, organizing them into patterns, categories, and basic units of description, distinguishing them from interpretation by giving significant meaning to the analysis, explaining the description patterns, and looking for relationships between the dimensions of the description. ${ }^{26}$ In formulating conceptions of the framework, it is possible to use the formulas contained in the legislation that forms the basis of the research or to be researched. ${ }^{27}$

In this analysis technique, the step taken is to collect legal materials, both primary legal materials, and secondary legal materials, related to the legal rules related to alternative dispute resolution. Indonesia reformed national arbitration law when the monetary crisis hit Indonesia in 1999, along with efforts to reform national economic law. Many have speculated that the renewal of Indonesia's arbitration law in 1999 was part of a policy package requested by the International Monetary Fund (IMF) to restore foreign investors' confidence in the Indonesian legal system. ${ }^{28}$

Renewal of Indonesian arbitration law is carried out by promulgating Law No. 30/1999 concerning Arbitration and the Alternative Settlement of Disputes. Law No. 30/1999 replaces the old Indonesian arbitration law as regulated in Articles 615 through Article 651 of the Reglement op de Burgerlijk Rechtsvordering (S. 1847: 52 jo. S. 1849: 63) as a legacy from the Dutch East Indies Government. Law No. 30/1999 did not adopt the

26 Iskandar, Metode Penelitian Kualitatif, Jakarta. Gaung Persada, 2009, p. 136.

${ }^{27}$ Soerjono Soekanto, Pengantar Penelitian Hukum, UI-PRESS, 2008, p.53

28 See: "Memorandum of Economic and Financial Policies" in The Jakarta Post, 15 May 1999, p. 5. In a document entitled "Supplementary Memorandum of Economic and Financial Policies - the Fifth Review under the Extended Agreement" attached to the letter of the Coordinating Minister for Economy, Finance and Industry to the IMF dated May 14, 1999 stating, among others, that the draft arbitration law has been submitted to the Parliament.
UNCITRAL Model Law, although some provisions have regulations that are identical to the provisions in the UNCITRAL Model Law.

The object of the arbitration arrangement in Law No. 30/1999 relatively complete includes: arbitration agreements, restrictions on court intervention, the appointment of arbitrators, renegotiation rights, the resignation of the arbitrator, arbitration award, implementation of domestic/international arbitration award and cancellation of the arbitration award. ${ }^{29}$ Even the object of regulation that should be sufficiently regulated in the arbitration procedure (arbitration rules and procedure), as a procedural law agreed upon by the parties, for the examination of cases in the arbitration is also regulated in Law No. 30/1999. It seems that the legislators intended to consolidate both arbitration law (lex arbitration) and the arbitration procedure in one legal document. ${ }^{30}$

In the process of settling disputes through arbitration, the parties clearly state that they want the dispute resolution through arbitration. They also have clearly stated whom they will appoint as the arbitrator who will resolve their dispute, what procedures must be taken, how does the (arbitrators) settle the dispute, how long must the dispute have been resolved, and what is the nature of the award handed down by the (arbitrators). Article 615 paragraph (1) Rv, describes: "It is permissible for anyone involved in a dispute concerning the rights which are in his power to release it, to submit the termination of the dispute to one or several referees. ${ }^{31}$

Preventive efforts to face the possibility of a dispute that is by including a clause on dispute

29 Compare: Alan Tsang, "Determining The Law Applicable to Arbitration Agreement: The Common Law Approach" dalam Mealey's International Arbitration Report, Vol. 29 No. 5, May 2014,, King of Prussia, Pennsylvania, p. 1

ssee Mulyana dan Jan K. Schaefer, “Indonesia's New Framework for International Arbitration: A Critical Assessment of the Law and Its Application by the Courts" in Mealey's International Arbitration Report, Vol. 17 No. 1, January 2002, King of Prussia, Pennsylvania, p. 4.

${ }^{31}$ Gunawan Widjaja, and AhmadYani, Op. Cit, p.17 
resolution in their agreement. The clause was titled Settlement of Disputes, which contained an agreement on which forum would settle disputes between parties, whether through court or arbitration. This is based on the principle of freedom of contract, which is one of the universally recognized universal principles. If the dispute resolution chosen is arbitration, the governing rules are contained in Law No. 30 of 1999 concerning Arbitration and Alternative Dispute Resolution. Article 3 of Law No. 30 of 1999 states that the court is not authorized to adjudicate disputes of parties who have been bound by an arbitration agreement. There are several important meanings contained in an arbitration clause, namely: ${ }^{32}$

1. With the inclusion of the arbitration clause, if there is a dispute between the parties, they have agreed to choose the arbitration that has been determined to settle their dispute. Thus the case is absolutely in the authority of the arbitration rather than the ordinary judicial institution. With the existence of an arbitration clause, the parties are subject to the rules that apply to the chosen arbitration institution. For example, the parties have chosen the Indonesian National Arbitration Board (BANI) as a forum to resolve their disputes, so the parties must submit to the rules of law of BANI;

2. Following the principle of the servanda sunt pact, which states that the agreement applies as a law, then with the existence of an arbitration clause, the parties are bound to settle disputes at the agreed arbitration institution.

The implementation of the national arbitration award is regulated in Articles 59-64 of the Arbitration Law, so that a decision can be implemented then the decision must be submitted and registered with the district court clerk by registering and submitting an original or authentic copy of the national arbitration award by the arbitrator or his attorney to the State NCourt Clerk, within 30 (thirty) days after the decision of the arbitration is pronounced. Non-fulfillment of the registration requirements before the 30 (thirty) days may make the arbitrator's decision impossible.

The Chair of the District Court is not authorized to examine the national arbitration award's reasons or considerations. The authority to examine the Chair of the District Court is limited to the formal examination of the national arbitration award handed down by the arbitrator or the arbitral tribunal. This is because national arbitration awards are independent, final, and binding (such as decisions that have permanent legal force).

Thus, the court still has a very large role in the resolution of disputes between the parties in developing the occurrence of the arbitration process or by overriding the existence of an arbitration clause in the agreement. The court still has an important role in resolving business disputes, even though the parties have agreed to resolve the dispute concerned through the Arbitration Board. ${ }^{33}$

So that in reality, the final nature of the arbitration award is not necessarily applicable because the provisions of Law No. 30 of 1999 concerning Arbitration and Alternative Dispute Resolution regulating the procedure for implementing the arbitration award, it is also possible that parties who are dissatisfied with the arbitration award can request cancellation of the decision. No final arbitration award is more visible in the dualism of business dispute resolution through bankruptcy and arbitration. The dualism of litigation and nonlitigation dispute resolution also has an impact on bankruptcy matters, because they are still included in commercial and civil law. This provides a conflict of authority that similarly regulates the settlement mechanism.

Implementation of Law No. 30/1999 is not without records. Many observers of arbitration law provide notes in several cases that are prominent and attract the attention of arbitration law observers and business people who conduct business activities in Indonesia. Just to mention as in the case of PT
${ }^{32} \mathrm{H}$. Adolf, Hukum arbitrase komersial internasional. Bandung: Keni Media, Tahun 2016, p. 17.
33 Erman Rajagukguk, Arbitrase Dalam Putusan Pengadilan,Jakarta: Chandra Pratama, 2000, p.15 
Pertamina (Persero) against Karaha Bodas Company L.L.C. and PT PLN (Persero), ${ }^{34}$ wherein its decision, surprisingly, the Central Jakarta District Court overturned the ad-hoc arbitration award handed down in Geneva, Switzerland; However, later the decision of the Central Jakarta District Court was canceled at the cassation level by the Supreme Court on the basis that the Central Jakarta District Court did not have the competence to cancel the arbitral award handed down in Geneva, Switzerland. ${ }^{35}$ The Central Jakarta District Court decided not only without a basis of authority, because it canceled the Swiss arbitration award, but also canceled the arbitration award based on reasons outside Article 70 of the Law. 30/1999. The Central Jakarta District Court overturned the arbitration award Geneva, Switzerland, by stating that the arbitration award, following the petitioner's argument, was contrary to public order in force in Indonesia. But it is unfortunate, the Supreme Court at the cassation level in the review of the decision on the cancellation request, did not consider the reason for the cancellation applied by the Central Jakarta District Court; The Supreme Court bases its decision only on aspects of authority that are not owned by the Central Jakarta District Court to cancel the arbitration award, the authority to cancel the arbitration award rests with the Swiss court as the country where the arbitration award was handed down. ${ }^{36}$

PT Pertamina Persero's case against Karaha Bodas Company L.L.C. and PT PLN (Persero) is a test case for the cancellation of the first arbitration award for the Supreme Court by referring to Law No. 30/1999. As the first test case for the Supreme Court in the case of requesting an annulment of an arbitration award, a decision on appeal and a review of the case of PT. Pertamina Persero against Karaha Bodas Company L.L.C. and PT PLN

34 PT Pertamina (Persero) against Karaha Bodas Company L.L.C. and PT PLN (Persero),PN Jakarta Pusat, No. 86/Pdt.G/2002/PN.Jkt, 27 August 2002

35 PT Pertamina (Persero) against Karaha Bodas Company L.L.C. and PT PLN (Persero), MARI, No. 01 / Appeal / Referee.Int / 2002, 8 March 2004; the cassation decision was requested for a review which was rejected by
(Persero) which did not provide legal considerations regarding the reason for canceling the arbitration award outside Law No. 30/1999 seems to set a precedent for requests to cancel a subsequent arbitration award to use reasons outside the provisions of Law No. 30/1999.

Another example of an arbitration case which was finally settled through the Commercial Court is a dispute case between PT. Atmindo with PT. Palmechandra Abadi, with the decision of the Indonesian National Arbitration Board (BANI) Medan Representative Number 01 / IV / ARB / BANI-Mdn / 2006 on January 27, 2007. In its decision BANI Medan Representative decided to punish PT. Palmechandra Abadi to pay the remaining payment for the cost of replacing spare parts in the procurement of palm oil mill boiler equipment (PKS) in Palembang in the amount of $650,979,463$ IDR within 30 days of the award being pronounced. But in its implementation, PT. Palmechandra Abadi could not fulfill its obligations as specified in the arbitration award, so PT. Palmechandra Abadi, who also has obligations or debts that have not been paid against several other creditors, was finally sued for bankruptcy. In the case of bankruptcy Number 03 / Bankrupt / 2007 / PN.Niaga.Mdn, PT. Atmindo and PT. Krida Pujimulyo Lestari and PT. Bank Bukopin Medan Branch together became the creditors of PT. Palmechandra Abadi in the bankruptcy case. it shows that although the BANI decision has permanent legal force to be implemented, but the practice is still constrained in implementing the BANI decision concerning payment of debt obligations.

The Arbitration Law regulates the cancellation of the Arbitration award in Article 70 which states that the parties may submit a request for cancellation if the arbitration award is alleged to contain elements of falsification of letters or documents, or found

MARI in PT Pertamina (Persero) against Karaha Bodas Company L.L.C. and PT PLN (Persero), MARI, No. 444 PK / Pdt / 2007, 9 September 2008.

${ }^{36}$ See: PT Pertamina (Persero) against Karaha Bodas Company L.L.C. and PT PLN (Persero),MARI, No. 01/Banding/Wasit.Int/2002, 8 March 2004. 
documents that are hidden by the opposing party, or the decision is taken from the results of deception deception carried out by one of the parties in the examination of disputes. However, in the practice of annulment of arbitration award based on Article 70 by the District Court until the Supreme Court is decided inconsistently. On the one hand, the Supreme Court overturned the Arbitration award only based on the reasons contained in Article 70, namely the Supreme Court ruling Number 727 / K / Pdt.Sus / 2008. In this case Article 70 is interpreted as limitative, on the other hand the Supreme Court states that the cancellation of an arbitration award can be carried out based on reasons outside Article 70, namely the Decision of the Supreme Court Number 03 / Arb / Btl / 2005. The inconsistency of the Supreme Court's decision regarding the annulment of the arbitral award refers to Article 70 of the Arbitration Act, giving rise to two streams, namely: ${ }^{37}$

The Supreme Court which is consistent with Article 70 which states that the reason for canceling an arbitral award must refer to the content of Article 70 and Article 70 of the Arbitration Law is limitative. It becomes jurisprudence in Decision MARI No.729 / K / Pdt.Sus / 2008, so that the annulment of an arbitration award that does not refer to Article 70 cannot be justified.

The second stream in which the Supreme Court declared Article 70 was not limited and was recognized and became jurisprudence in MARI Decision No. 03 / Arb.BTU 2005 dated May 17, 2005 stated the word "among other things" in the General Explanation of the Arbitration Law allowing the Petitioner to submit application for cancellation of arbitration award for reasons other than those contained in Article 70 of the Arbitration Law. Certainly the Supreme Court's Decision creates injustice and legal uncertainty for the parties to the dispute.

${ }^{37}$ Yeni Widowaty, Fadia Fitriyanti. Inconsistency of Supreme Court Decision in Canceling Arbitration Award. Journal of Legal Media. Vol.23 NO.2 / December 2016. Faculty of Law, University of Muhammadiyah Yogyakarta, p. 211
In Islam it is regulated about how the justice system must also be upheld and implemented, this is what is done in order to uphold the truth and justice. A judge is in charge of giving fair decisions to the parties to the litigation. Indeed, the real justice is justice which is based on the teachings revealed by Allah SWT to the Prophet Muhammad SAW as stated in the Koran in At-tin verse 8 which reads: "Doesn't this mean that God is not the fairest judge and also as stated in the Surah Al-Imran verse 18 which reads, "It means that Allah declares that there is no god but He (who is entitled to worship), who upholds justice, angels and those who have knowledge (also declares such), there is no God but $\mathrm{He}$ ( who is entitled to worship), the Mighty, the Most Wise ".

Likewise the judges who examine a case are required to be fair and the judges must also give a fair decision. In carrying out their duties the judge may not accept bribes in any form with the aim of winning or giving advantages to one party and giving a large loss to the other party.

As stated in Surah Al-Baqarah verse 188 which reads: "And let not some of you eat the treasure of the other half of you in a false way and (do not) bring it to the judge, so that you may eat some of the property of others it with (the way to sin), But you know ".

In examining arbitration cases, the arbitral tribunal must be able to examine the case and examine the sacraments and evidence submitted by the disputing party and give the fairest verdicts and make decisions that benefit both parties to the dispute.

In the hadith narrated by Al-Bukhori and Muslims and Umm Salamah, the Prophet Muhammad S.A.W once said that if there is a judge who decides a case without hearing both parties, then the decision is the same as a piece of hellfire. ${ }^{38}$

The need for reconstruction of the provisions in Article 36, Article 46, and Article 70 of Law No.

38. Taifiq Rahman, Hadis-Hadis Hukum, Bandung, Pustaka Setia Publisher, 2000, page 63 
30 of 1999 concerning Arbitration and Alternative Dispute Resolution.

\section{Clonclusion}

The implementation of dispute resolution outside the court has not been effective, because it has not provided legal certainty and justice. Weaknesses in the regulation of dispute resolution through arbitration, namely:

Weaknesses in the arrangement of third parties outside the arbitration agreement may involve joining the dispute resolution process through arbitration, if there are elements of interest involved and participation agreed by the parties to the dispute and agreed by the arbitrator or the arbitral tribunal examining the dispute in question. This provision is regulated in article 30 of Law No. 30 of 1999. The problem arising under this provision is that there are no clear provisions governing who can be said to be a third party outside the agreement, which is based on the principle of pacta sunt servanda then in an agreement an agreement is only based on the agreement of the parties making agreement. This provision becomes a multi-interpreted provision; this is due to the weak regulation of the provisions of third parties who want to join in the process of dispute resolution through arbitration. Besides that, in the explanation of Article 30 it is also explained that the provision is quite clear.

Weaknesses regarding the evidentiary system by the parties in arbitration, which in Law No. 30 of 1999 did not mention the obligations of the parties to show the original letter or other written document. Including the non-regulation or provisions regarding the manner or opportunity given to the parties to the dispute in obtaining evidence and or statements of witnesses relating to the arbitration dispute, this is related to the existence of documentary evidence or other written documents at the party thirdly and also the existence of witnesses whose statements cannot be asked in relation to the ongoing arbitration dispute. The next weakness is about the cancellation system of arbitration award, where in article 70 of Law no. 30 of 1999 states that against an arbitration award the parties may submit a request for cancellation if the decision is alleged to contain the following elements:

a letter or document submitted during examination, after the decision has been handed down, is acknowledged to be false or declared to be false; after the decision has been taken, decisive documents are found, which are hidden by the opposing party; or

the decision is taken from the results of a ruse carried out by one of the parties in the examination of the dispute.

The provision contained in article 70 letter (a) constitutes a form of fraud or deception committed by one of the parties to the dispute. Then the existence of article 70 letter (a) includes elements of fraud or deception carried out by the parties to the dispute in arbitration.

\section{REFERENCES}

[1] Alan Tsang, "Determining The Law Applicable to Arbitration Agreement: The Common Law Approach" dalam Mealey's International Arbitration Report, Vol. 29 No. 5, May 2014,, King of Prussia, Pennsylvania

[2] Djoko Imbawani Atmadjaja, Hukum Dagang Indonesia Sejarah, Pengertian dan Prinsip -prinsip Hukum Dagang, Cetakan ke-2, Malang: Setara Press, 2012

[3] Enid E. Marshall, Gill: the Law of Arbitration,Sweet\& Maxwell, London, 2001

[4] Erman Rajagukguk, Arbitrase Dalam Putusan Pengadilan,Jakarta: Chandra Pratama, 2000

[5] Frans Hendra Winarta, Hukum Penyelesaian Sengketa Arbitrase Nasional Indonesia dan Internasional, Cetakan ke2, Jakarta: Sinar Grafika, 2013

[6] Gatot Soemartono, Arbitrase dan Mediasi di Indonesia, Jakarta, Gramedia Pustaka Utama, 2006

[7] Gunawan Widjaja dan Ahmad Yani. Seri Hukum Bisnis : Hukum Arbitrase.Jakarta : PT Raja Grafindo Persada 2000. 
[8] Hayadi, M. Penyelesaian Bisnis Internasional melalui Arbitrase. Jurnal ilmu hukum, 2009

[9] Iskandar, Metode Penelitian Kualitatif, Jakarta. Gaung Persada, 2009

[10] Jazim Hamidi, Hermenetika Hukum, Yogyakarta, UII Press, 2005

[11] Joejoen Tjahjani. Peran Pengadilan dalam pelaksaan putusan arbitrase. Jurnal Independent Vol. 2 No. 1.

[12] Mardalis, Metode Penelitian Suatu Pendekatan Proposal, Bumi Aksara, 1989

[13] Mulyana dan Jan K. Schaefer, "Indonesia's New Framework for International Arbitration: A Critical Assessment of the Law and Its Application by the Courts" in Mealey's International Arbitration Report, Vol. 17 No. 1, January 2002, King of Prussia, PennsylvaniaH. Adolf, Hukum arbitrase komersial internasional. Bandung: Keni Media, Tahun 2016.

[14] Nugroho, J. Kajian Kritis Terhadap UU No 3 Tahun 1999 tentang Arbitrase dan Alternatif Penyelesain Sengketa Dalam Kaitannya Dengan Prinsip Kebebasan Berkontrak di Indonesia. Jurnal Hukum Argumentum, 2005

[15] Soerjono Soekanto, Pengantar Penelitian Hukum, UI-PRESS, 2008

[16] Soetandyo Wignjosoebroto, Hukum Paradigma, Metode dan Dinamika Masalahnya, Huma, Jakarta, 2002

[17] Suyud Margono, ADR (Alternative Dispute Resolutian) dan Arbitrase Proses Pelembagaan dan Aspek Hukum. Jakarta : Ghalia Indonesia, 2004

[18] Taifiq Rahman, Hadis-Hadis Hukum, Bandung, Pustaka Setia Publisher, 2000

[19] UNCITRAL, Digest of Case Law on the Model Law on International Commercial Arbitration, United Nations publication, Sales No. E.12.V.9, New York, 2012

[20] Yeni Widowaty, Fadia Fitriyanti. Inconsistency of Supreme Court Decision in Canceling Arbitration Award. Journal of www.psychologyandeducation.net
Legal Media. Vol.23 NO.2 / December 2016. Faculty of Law, University of Muhammadiyah Yogyakarta

[21] Zaeni Asyhadie, Hukum Bisnis Prinsip dan Pelaksanaannya di Indonesia, 5th edition, Jakarta: Rajawali Pers, Tahun 2011 